\title{
Prognostic significance of miR- 126 in various cancers: a meta-analysis
}

\author{
This article was published in the following Dove Press journal: \\ OncoTargets and Therapy \\ 28 April 2016 \\ Number of times this article has been viewed
}

\section{Yuanli Dong ${ }^{1,2}$ \\ Chengrui Fu² \\ Hui Guan ${ }^{2}$ \\ Zicheng Zhang ${ }^{2}$ \\ Tao Zhou ${ }^{2}$ \\ Baosheng $\mathrm{Li}^{2}$}

'School of Medicine and Life Sciences, University of Jinan, Shandong Academy of Medical Sciences, Jinan, Shandong Province, ${ }^{2}$ Sixth Department of Radiation Oncology, Shandong Cancer Hospital \& Institute, Jinan, Shandong Province, People's Republic of China

Correspondence: Baosheng Li

Sixth Department of Radiation Oncology, Shandong Cancer Hospital and Institute, 440 Jiyan Road, Jinan 250I I7, Shandong Province, People's Republic of China

Tel +86 I3954I6 8847

Fax +86 53I 67626161

Email baoshli1963@163.com
Objective: Recent studies have demonstrated that microRNA-126 (miR-126) might be a promising prognostic factor for cancer patients. This meta-analysis was conducted to assess the effectiveness of miR-126 as a prognostic biomarker for various cancers.

Methods: The search of studies was performed by using PubMed and Embase until January 22, 2016. Pooled hazard ratio (HR) with $95 \%$ confidence interval (CI) for patients' survival was calculated. A fixed-effect or random-effects model was applied according to heterogeneity. The trim and fill method was used to adjust pooled HR.

Results: In all 17 articles comprising of 2,437 participants were included in this meta-analysis. The results indicated that a high level of miR-126 played a favorable role in the overall survival (HR $0.70,95 \%$ CI: $0.62-0.79$, random-effects model), with a heterogeneity measure index of $I^{2}=63.2 \%(P<0.01)$. Subgroup analyses showed that pooled HR was more significant in patients with digestive system cancers (HR 0.70, 95\% CI: 0.59-0.83, fixed-effects model) and respiratory system cancers (HR $0.71,95 \% \mathrm{CI}: 0.59-0.85$, random-effects model). Owing to publication bias, HR was adjusted to $0.59(0.463-0.752, P<0.01)$ by the trim and fill method. Conclusion: miR-126 could be a promising biomarker for cancer prognosis prediction, especially in patients with digestive or respiratory system cancers.

Keywords: cancer, miR-126, prognosis

\section{Introduction}

MicroRNAs (miRNAs) are a class of highly conserved noncoding RNAs with a length of 22 nucleotides that participate in a wide range of biological processes, such as proliferation, differentiation, and apoptosis. ${ }^{1}$ Depending on the complementarity between miRNA and mRNA, they inhibit gene expression mostly by binding to 3 '-untranslated region of target mRNAs, which leads to degradation or inhibition of the target mRNA translation. Notably, the research by Calin et al was the first to associate miRNAs with cancers. They reported that miRNA-15 and miRNA-16 were downregulated in $68 \%$ of chronic lymphocytic leukemias. ${ }^{2}$ Since then, an increasing number of investigations across the globe began to focus on miRNA's role in different types of cancers. To date, hundreds of miRNAs were discovered. It was further demonstrated that certain types of cancers featured distinct miRNA expression profiles. ${ }^{3,4}$

Located within the seventh intron of epidermal growth factor-like protein 7 gene (EGFL7) on human chromosome 9, microRNA-126 (miR-126) is often expressed in endothelial cells, behaving to mediate angiogenesis and inflammation. ${ }^{5}$ In most cases, miR-126 functions as a tumor suppressor. ${ }^{6-9}$ Nonetheless, in other instances, it is more complicated or even helps to promote carcinogenesis and cancer progression. ${ }^{10,11}$ Recent years have seen many studies concentrating on the association of miR-126 and cancer prognosis, ${ }^{12-28}$ which may not only provide a promising target for future cancer 
treatment in the long term but also give some insights into whether miR-126 could be used as a prognostic biomarker in related scientific research or clinical trials in the short term. Generally, loss of miR-126 was a negative prognostic factor, ${ }^{19,20}$ but similar to the results of in vitro study, their relationship is not consistent. ${ }^{23,28}$ Thus, the present study was conducted to evaluate whether miR-126 could serve as prognostic classifiers in a variety of cancers.

\section{Materials and methods}

\section{Search strategy}

The search of studies was performed by using PubMed and Embase (updated by January 22, 2016). The following keywords were applied simultaneously: "(microRNA-126 or miR-126 or mir126) and (tumor or neoplasm or cancer or cancer or malignancy)". Potentially related studies were also collected from the reference lists. The comprehensive database search was carried out independently by two authors (Dong and $\mathrm{Fu}$ ).

\section{Inclusion and exclusion criteria}

Studies were considered eligible if they met the following criteria: 1) investigated any cancer; 2) measured dichotomous
miR-126 expression levels in tissue or blood, namely, survival data were presented as high-level expression group versus low-level expression group; and 3) analyzed association between miR-126 expression levels and overall survival (OS). Review articles or letters, non-English articles, editorials, laboratory studies, studies with nondichotomous miR-126 expression levels (eg, survival data divided by tertiles), and studies investigating a set of miRNAs were all excluded. If hazard ratio (HR) and 95\% confidence interval (CI) could not be extracted from the articles due to the absence of key information, then these studies were not included in the analysis (Figure 1).

\section{Data extraction}

Data extraction was first performed carefully by Guan and Fu and subsequently checked by Zhou. Moreover, search was performed again in the excluded articles by Dong and Li in order to not miss any potentially related study. The extracted data elements of this review included the following: 1) publication details: first author's last name and publication year; 2) characteristics of the studied population: sample size, disease, and stage of disease; 3) miR-126 assessment and cutoff definition; and 4) HR of elevated miR-126 for OS, as well as

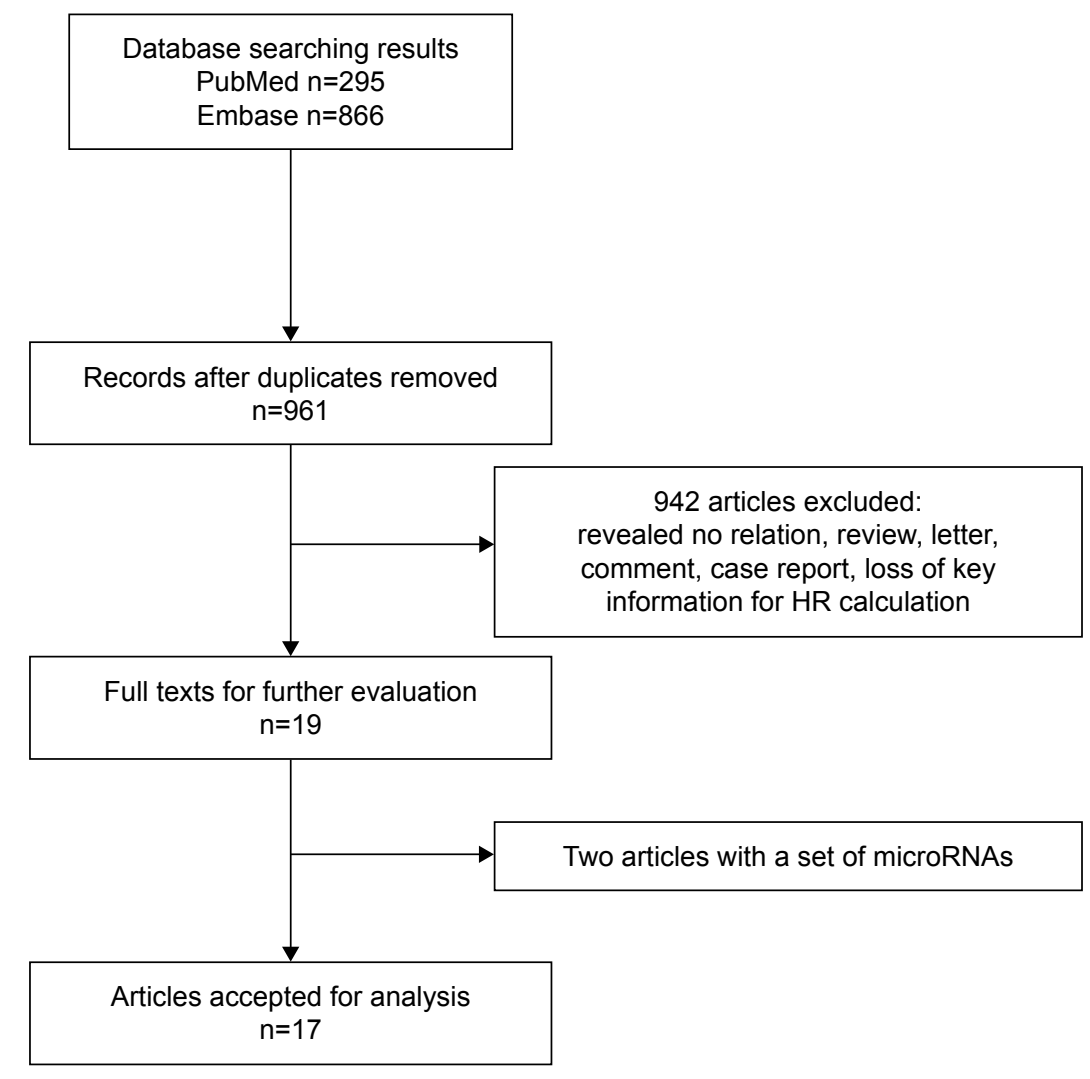

Figure I Flow diagram depicting the selection process of eligible studies. Abbreviation: HR, hazard ratio. 
their $95 \% \mathrm{CI}$ and $P$-value. The simplest method consisted of direct collection of HR and their 95\% CI from the original article or from authors, with an HR of $>1$ being associated with a poor outcome. If only Kaplan-Meier curves were available, data were extracted from the graphical survival plots and estimation of the HR was then performed using the described method. ${ }^{29}$

\section{Qualitative assessment}

Newcastle-Ottawa scale was used to assess the methodological quality of studies incorporated in this meta-analysis, which was judged on three aspects: the selection of the study groups, the comparability of the groups, and the outcome of interest, respectively. ${ }^{30-32}$ The lowest score was 0 and the highest was 9 . Studies with a score $<5$ in the present study were not included in the final analysis.

\section{Statistical analysis}

Cochran's $Q$ test and Higgin's $I^{2}$ statistic was used to measure between-study heterogeneity. If heterogeneity did exist $(P<0.05)$, random-effects model (DerSimonian and Laird method) was applied to calculate pooled HR. If not, fixedeffects model was used. Subgroup analysis, sensitive analysis, and meta-regression were further applied to investigate sources of heterogeneity. Publication bias was assessed by Begg's test and Egger's test. ${ }^{33,34}$ If a publication bias did exist, the Duval and Tweedie's trim and fill method was used to adjust the results. ${ }^{35}$ Stata Version 12.0 (StataCorp LP, College Station, TX, USA) was used in all analyses. A $P$-value of $<0.05$ was considered to be statistically significant.

\section{Results}

\section{Summary of analyzed studies}

By searching PubMed and Embase, a total of 1,161 records for miR-126 were collected. Then, 200 duplicate records were removed. In all, 941 studies did not meet the eligibility criteria. Two studies investigated a set of miRs but not miR-126 alone. ${ }^{36,37}$ At last, 17 studies were included in the final meta-analysis that had a total of 2,437 patients from the USA, Denmark, the Netherlands, Serbia, Canada, South Korea, Japan, and the People's Republic of China. The types of carcinomas included non-small cell lung cancer (NSCLC), esophageal cancer, colorectal cancer (CRC), hepatocellular carcinoma, clear-cell renal cell carcinoma, adult T-cell leukemia, acute myeloid leukemia, and cervical cancer, osteosarcoma, melanoma, and laryngeal squamous cell carcinoma. Ten studies $(n=842)$ included Asian patients. Four studies $(n=602)$ concentrated on respiratory system disease. Seven articles $(n=1,088)$ focused on digestive system diseases. Tissue specimens were used in 14 studies. In situ hybridization (ISH) was applied in three studies. Quantitative real-time polymerase chain reaction (qRT-PCR) was used in 14 studies. Details of the key information in the final metaanalysis are listed in Table 1.

\section{Qualitative assessment}

Newcastle-Ottawa scale revealed that the study quality varied from 5 to 8 , with a mean of 6.5 (Table 2). All the 17 studies were included in the final analysis.

\section{OS associated with miR- 126 expression}

Because of the significant heterogeneity $\left(I^{2}=63.2 \%, P<0.01\right)$, random-effects model was performed, indicating that higher level of miR-126 significantly predicted better OS (HR 0.70, 95\% CI: 0.62-0.79, random-effects model; Figure 2). Subgroup analysis was further conducted according to the main characteristics, which demonstrated that the predictive role of miR-126 was especially significant in digestive system cancers (HR 0.70, 95\% CI: 0.59-0.83, fixed-effects model) and respiratory system cancers (HR 0.71, 95\% CI: 0.59-0.85, random-effects model). In addition, the association was also significant in other subgroups, including Asian patients (HR 0.67, 95\% CI: 0.58-0.77, fixed-effects model), white patients (HR 0.76, 95\% CI: 0.63-0.92, random-effects model), studies testing tissue specimen (HR 0.68, 95\% CI: 0.60-0.76, random-effects model), miR-126 assay by qRTPCR (HR 0.70, 95\% CI: 0.61-0.79, random-effects model), and HR obtained by report (HR 0.69, 95\% CI: 0.61-0.79, random-effects model). Details are listed in Table 3.

\section{Heterogeneity analysis}

The subgroup analysis showed different prognostic powers in miR-126 (tissue or blood), miR-126 assay method (ISH or qRT-PCR), and data source (reported or extracted from the survival curve). The sensitivity analysis demonstrated that there was no significant change in heterogeneity, no matter which article was excluded (Figure 3). Moreover, meta-regression analysis was performed to further identify the source of heterogeneity, showing that heterogeneity may be induced by disease types $\left(I^{2}=59.74 \%\right.$, adjusted $\left.R^{2}=17.4 \%\right)$ and data source $\left(I^{2}=60.35 \%\right.$, adjusted $\left.R^{2}=15.75 \%\right)$, although neither reached statistical significance $(P>0.05)$.

\section{Publication bias}

We performed Begg's and Egger's tests to assess potential publication bias. ${ }^{33,34}$ The value was 0.064 for Begg's test and 
Table I A summary table of the meta-analysis

\begin{tabular}{|c|c|c|c|c|c|c|c|c|c|c|c|}
\hline Study & Year & $\begin{array}{l}\text { Origin of } \\
\text { population }\end{array}$ & Tumor type & $\begin{array}{l}\text { Sample } \\
\text { number }\end{array}$ & Stage & $\begin{array}{l}\text { Follow-up } \\
\text { (months) }^{\mathrm{a}}\end{array}$ & $\begin{array}{l}\text { Source } \\
\text { of RNA }\end{array}$ & $\begin{array}{l}\text { miR-I26 } \\
\text { assay }\end{array}$ & Cutoff & $\begin{array}{l}\text { Hazard } \\
\text { ratio }\end{array}$ & $\begin{array}{l}\text { Multivariate } \\
\text { analysis }\end{array}$ \\
\hline Hu et al $^{12}$ & 2011 & USA & EC & 99 & NR & 256.43 & Tissue & $\mathrm{ISH}$ & $\begin{array}{l}\text { Staining intensity } \\
(+,++,+++)\end{array}$ & Report & Yes \\
\hline $\begin{array}{l}\text { Hansen } \\
\text { et al }{ }^{13}\end{array}$ & 2011 & Denmark & CRC & 81 & I-IV & NR & Tissue & $\mathrm{ISH}$ & Median & Report & No \\
\hline $\begin{array}{l}\text { Hansen } \\
\text { et al }{ }^{14}\end{array}$ & 2012 & Denmark & CRC & 83 & IV & NR & Tissue & $\mathrm{ISH}$ & Median & $\mathrm{DE}$ & No \\
\hline $\begin{array}{l}\text { Ishihara } \\
\text { et al }{ }^{15}\end{array}$ & 2012 & Japan & ATL & 35 & NR & NR & Blood & qRT-PCR & Median & $\mathrm{DE}$ & No \\
\hline $\begin{array}{l}\text { Yang } \\
\text { et al }\end{array}$ & 2012 & $\begin{array}{l}\text { People's Republic } \\
\text { of China }\end{array}$ & NSCLC & 442 & I-IV & $60 *$ & Tissue & qRT-PCR & Median & Report & Yes \\
\hline $\begin{array}{l}\text { Jusufović } \\
\text { et al }{ }^{17}\end{array}$ & 2012 & Serbia & NSCLC & 50 & II-IV & NR & Tissue & qRT-PCR & Median & Report & No \\
\hline $\begin{array}{l}\text { Han } \\
\text { et } \mathrm{al}^{18}\end{array}$ & 2012 & $\begin{array}{l}\text { People's Republic } \\
\text { of China }\end{array}$ & $\mathrm{HCC}$ & 105 & I-IV & 42.89 & Tissue & qRT-PCR & Fold change $=2$ & Report & No \\
\hline $\begin{array}{l}\text { Chen } \\
\text { et a }\left.\right|^{19}\end{array}$ & 2013 & $\begin{array}{l}\text { People's Republic } \\
\text { of China }\end{array}$ & $\mathrm{HCC}$ & 68 & I-III & 49 & Tissue & qRT-PCR & 0.7 (ROC curve) & $\mathrm{DE}$ & No \\
\hline Liu et $\mathrm{a}^{20}$ & 2014 & $\begin{array}{l}\text { People's Republic } \\
\text { of China }\end{array}$ & CRC & 92 & I-IV & 65 & Tissue & qRT-PCR & Median & Report & Yes \\
\hline $\begin{array}{l}\text { Kim } \\
\text { et } \mathrm{al}^{21}\end{array}$ & 2014 & South Korea & NSCLC & 72 & I-IV & 31 & Tissue & qRT-PCR & Median & Report & Yes \\
\hline $\begin{array}{l}\text { Hansen } \\
\text { et al }{ }^{22}\end{array}$ & 2014 & Denmark & CRC & 560 & II & 84 & Tissue & qRT-PCR & Median & Report & Yes \\
\hline $\begin{array}{l}\text { de Leeuw } \\
\text { et } \mathrm{al}^{23}\end{array}$ & 2014 & the Netherlands & AML & 92 & NR & NR & Blood & qRT-PCR & Median & $\mathrm{DE}$ & No \\
\hline $\begin{array}{l}\text { Yang } \\
\text { et a }\left.\right|^{24}\end{array}$ & 2014 & $\begin{array}{l}\text { People's Republic } \\
\text { of China }\end{array}$ & $\mathrm{CC}$ & 133 & I-IV & NR & Tissue & qRT-PCR & Median & Report & Yes \\
\hline $\begin{array}{l}\text { Sun } \\
\text { et } \mathrm{a}^{25}\end{array}$ & 2014 & $\begin{array}{l}\text { People's Republic } \\
\text { of China }\end{array}$ & LSCC & 38 & & NR & Blood & qRT-PCR & Median & $\mathrm{DE}$ & No \\
\hline $\begin{array}{l}\text { Liu } \\
\text { et } \mathrm{a}^{26}\end{array}$ & 2015 & $\begin{array}{l}\text { People's Republic } \\
\text { of China }\end{array}$ & Osteosarcoma & 122 & I-IV & NR & Tissue & qRT-PCR & Median & Report & Yes \\
\hline $\begin{array}{l}\text { Lin } \\
\text { et } \mathrm{a}^{27}\end{array}$ & 2015 & $\begin{array}{l}\text { People's Republic } \\
\text { of China }\end{array}$ & Melanoma & 108 & I-IV & NR & Tissue & qRT-PCR & Median & Report & Yes \\
\hline $\begin{array}{l}\text { Khella } \\
\text { et } \mathrm{a}^{28}\end{array}$ & 2015 & Canada & $\mathrm{RCC}$ & 257 & I-IV & NR & Tissue & qRT-PCR & 20th percentile & Report & Yes \\
\hline
\end{tabular}

Notes: The "*” denotes maximal survival. Cutoff is the standard used to define the expression level. aData presented as median.

Abbreviations: miR-126, microRNA-126; EC, esophageal cancer; NR, not reported; ISH, in situ hybridization; CRC, colorectal cancer; DE, data extrapolated; ATL, adult T-cell leukemia; qRT-PCR, quantitative real-time polymerase chain reaction; NSCLC, non-small cell lung cancer; HCC, hepatocellular carcinoma; ROC, receiver operating characteristic; AML, acute myeloid leukemia; CC, cervical cancer; LSCC, laryngeal squamous cell carcinoma; RCC, clear-cell renal cell carcinoma.

0.042 for Egger's test (Figure 4). Although no publication bias was revealed in Begg's test, Egger's test revealed publication bias. Thus, trim and fill method was performed to make pooled HR more reliable. The adjusted HR was 0.59 (0.432-0.752, $P<0.01)$.

\section{Discussion}

To date, miRNA expression profiling studies reported aberrant expression of miR-126 in a variety of cancers, including $\mathrm{CRC}$, esophageal cancer, hepatocellular carcinoma, acute myeloid leukemia, gastric cancer, thyroid cancer, breast cancer, oral cancer, and prostate cancer. ${ }^{38}$ Studies in vitro revealed complexity of miR-126 in the biological regulation. On one hand, it serves as a tumor suppressor. ${ }^{39-42}$ In terms of cell cycles, Miko et al discovered that small cell lung cancer cells were delayed in the G1 phase by miR-126 overexpression. ${ }^{39}$ Consistently, cell cycle progression from the G1/G0 phase to S phase was also inhibited by miR-126 in the breast cancer cell MCF-7. ${ }^{40}$ Targeting EGFL 7, miR-126 decreased angiogenesis factors such as vascular endothelial growth factor (VEGF) and fibroblast growth factor in oral squamous cell carcinoma cells. By contrast, transfection with miR-126 dramatically decreased cell proliferation, cell cycle progression, and cell invasion. ${ }^{41}$ In colon cancer, Li et al transfected miR-126 into CRC SW480 and HT-29, in which inhibited growth was observed. ${ }^{42}$ In addition, as is well known, epithelial-mesenchymal transition is generally regarded as the initial step toward distant metastasis. 
Table 2 Quality assessment based on the Newcastle-Ottawa scale

\begin{tabular}{|c|c|c|c|c|}
\hline Study ID & Selection & Comparability & Outcome & $\begin{array}{l}\text { Total } \\
\text { score }\end{array}$ \\
\hline $\mathrm{Hu}$ et $\mathrm{al}^{12}$ & 4 & 0 & 2 & 6 \\
\hline Hansen et $\mathrm{al}^{13}$ & 4 & 2 & I & 7 \\
\hline Hansen et $\mathrm{al}^{14}$ & 4 & I & I & 6 \\
\hline Ishihara et al $\left.\right|^{15}$ & 4 & 0 & I & 5 \\
\hline Yang et $\mathrm{al}^{16}$ & 4 & 2 & 2 & 8 \\
\hline Jusufović et al ${ }^{17}$ & 4 & 0 & $\bar{l}$ & 5 \\
\hline Han et $\mathrm{al}^{18}$ & 4 & 0 & 2 & 6 \\
\hline Chen et al ${ }^{19}$ & 4 & 2 & 2 & 8 \\
\hline Liu et $\mathrm{al}^{20}$ & 4 & I & 2 & 7 \\
\hline Kim et $\mathrm{al}^{21}$ & 4 & I & 2 & 7 \\
\hline Hansen et $\mathrm{a}^{22}$ & 4 & I & 2 & 7 \\
\hline de Leeuw et $\mathrm{a}^{23}$ & 4 & 0 & I & 5 \\
\hline Yang et $\mathrm{al}^{24}$ & 4 & I & 2 & 7 \\
\hline Sun et $\mathrm{a}^{25}$ & 4 & 2 & I & 7 \\
\hline Liu et $\mathrm{a}^{26}$ & 4 & I & I & 6 \\
\hline Lin et $\mathrm{a}^{27}$ & 4 & I & I & 6 \\
\hline Khella et $\mathrm{a}^{28}$ & 4 & I & I & 6 \\
\hline
\end{tabular}

Note: Selection: representativeness of studies (maximum score of 4). Comparability: comparability of studies based on the the design or analysis (maximum score of 2). Outcome: assessment of outcome and follow-up (maximum score of 3). For futher details see Wells et al. ${ }^{30}$
In pancreatic cancer cells, miR-126 was involved in this process by regulating disintegrin and metalloproteinase domain-containing protein 9 (ADAM9). Reexpression of miR-126 led to reduced cellular migration, invasion, and induction of epithelial marker E-cadherin. ${ }^{43}$ On the other hand, it was suggested that overexpression of exogenous miR-126 favored growth of gastric cancer cell lines by regulating its downstream target genes. These results suggested the complex behavior of miR-126, which may function either as an oncogene or as a tumor suppressor in biological activities. ${ }^{10}$ Numerous pathways participated in the function of miR-126. In breast cancer, miR-126 inhibited endothelial cell recruitment and angiogenesis by negatively regulating insulin-like growth factor-binding protein 2 /insulin-like growth factor $1 /$ insulin-like growth factor 1 receptor and growth arrest-specific 6/MERTK signaling pathways. ${ }^{44}$ Zhu et al revealed that miR-126 facilitated tumor genesis and growth by regulating the VEGF/phosphoinositide
Study ID

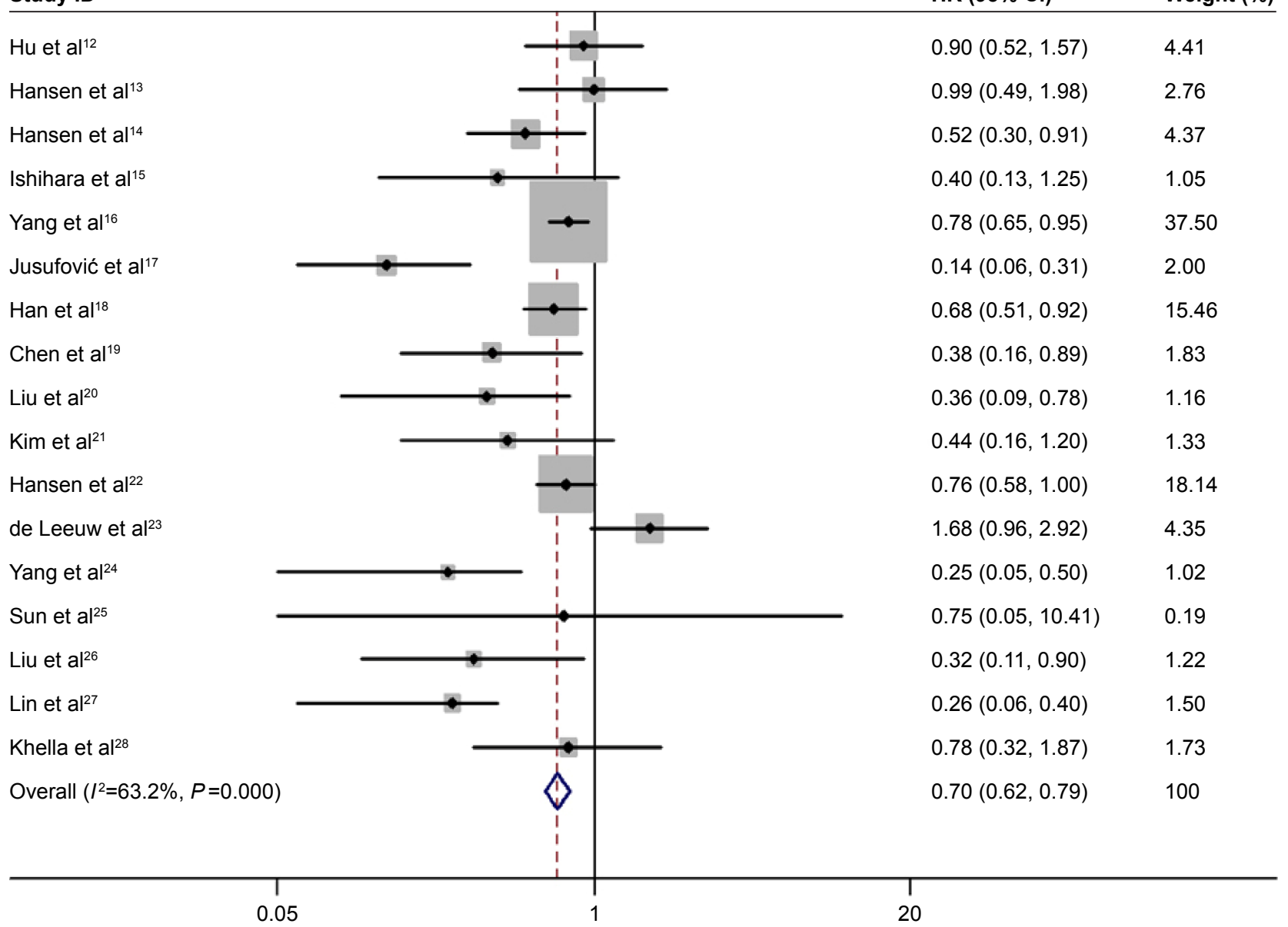

Figure 2 Forest plot of the relationship between miR-126 expression and OS.

Abbreviations: miR-126, microRNA-126; OS, overall survival; $\mathrm{Cl}$, confidence interval; $\mathrm{HR}$, hazard ratio. 
Table 3 Subgoup analysis

\begin{tabular}{|c|c|c|c|c|}
\hline Subgroup & $I^{2}(\%)$ & $P$-value & HR (95\% Cl) & $P$-value \\
\hline \multicolumn{5}{|l|}{ Origin of population } \\
\hline White patients & 77.6 & $<0.01$ & $0.76(0.63-0.92)^{\mathrm{a}}$ & 0.04 \\
\hline Asian patients & 42.1 & 0.08 & $0.67(0.58-0.77)^{b}$ & $<0.01$ \\
\hline \multicolumn{5}{|l|}{ Tumor type } \\
\hline $\begin{array}{l}\text { Digestive system } \\
\text { cancers }\end{array}$ & 9.9 & 0.35 & $0.70(0.59-0.83)^{\mathrm{b}}$ & $<0.01$ \\
\hline $\begin{array}{l}\text { Respiratory } \\
\text { system cancers }\end{array}$ & 82.2 & $<0.01$ & $0.71(0.59-0.85)^{\mathrm{a}}$ & $<0.01$ \\
\hline \multicolumn{5}{|l|}{ Source of RNA } \\
\hline Tissue & 60.3 & 0.02 & $0.68(0.60-0.76)^{\mathrm{a}}$ & $<0.01$ \\
\hline Blood & 60.9 & 0.08 & $1.25(0.76-2.04)^{b}$ & 0.38 \\
\hline \multicolumn{5}{|l|}{ miR-I26 assay } \\
\hline ISH & 25.9 & 0.26 & $0.75(0.53-1.05)^{\mathrm{b}}$ & 0.10 \\
\hline qRT-PCR & 68.0 & $<0.01$ & $0.7(0.61-0.79)^{a}$ & $<0.01$ \\
\hline \multicolumn{5}{|l|}{$H R$} \\
\hline Report & 63.2 & 0.02 & $0.69(0.6 \mathrm{I}-0.79)^{\mathrm{a}}$ & $<0.01$ \\
\hline DE & 70.0 & 0.01 & $0.75(0.54-1.05)^{\mathrm{a}}$ & 0.10 \\
\hline \multicolumn{5}{|l|}{ Cutoff } \\
\hline Median & 70.4 & $<0.01$ & $0.70(0.62-0.80)^{\mathrm{a}}$ & $<0.01$ \\
\hline Others & 0 & 0.42 & $0.69(0.54-0.88)^{b}$ & $<0.01$ \\
\hline \multicolumn{5}{|l|}{ Multivariate analysis } \\
\hline Yes & 42.9 & 0.08 & $0.72(0.63-0.83)^{\mathrm{b}}$ & $<0.01$ \\
\hline No & 75.8 & $<0.01$ & $0.66(0.54-0.8 \mathrm{I})^{\mathrm{a}}$ & $<0.01$ \\
\hline
\end{tabular}

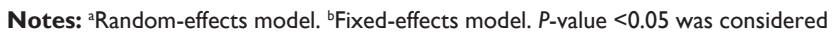
to be statistically significant.

Abbreviations: HR, hazard ratio; miR-126, microRNA- 126; ISH, in situ hybridization; qRT-PCR, quantitative real-time polymerase chain reaction; $D E$, data extrapolated; $\mathrm{Cl}$, confidence interval.
3-kinase/AKT signaling pathway. ${ }^{45} \mathrm{Li}$ et al demonstrated that miR-126 inhibited colon cancer cell proliferation and invasion via RhoA/ROCK signaling. ${ }^{46} \mathrm{~A}$ better understanding of miR-126 biological features is important to understand its role as a prognostic factor and its possible role as a treatment target.

During recent years, many efforts were made to explore the association between miRNAs and cancers in diagnosis, ${ }^{47}$ prognosis, ${ }^{48}$ and treatment response ${ }^{49}$ in order to find potential biomarkers to be used in future clinical practice. Undoubtedly, miR-126 is a promising one. Yang et al revealed that downregulation of miR-126 in NSCLC patients is correlated with worse OS (HR 0.782, 95\% CI: 0.647-0.945). ${ }^{16}$ Similar results were reported by Jusufović et al who discovered that lower miR-126 expression was a negative prognostic factor for both progression free survival (HR 0.10, 95\% CI: 0.04-0.21) and OS (HR 0.14, 95\% CI: 0.06-0.31) in NSCLC patients, which may be attributed to elevated tumor angiogenesis. ${ }^{17}$ Using qRT-PCR, Yang et al examined miR-126 expression level in human cervical cancer tissues and indicated that miR-126 was an independent prognostic factor (HR 3.97, 95\% CI: $2.01-20.22){ }^{24}$ The potential prognostic role

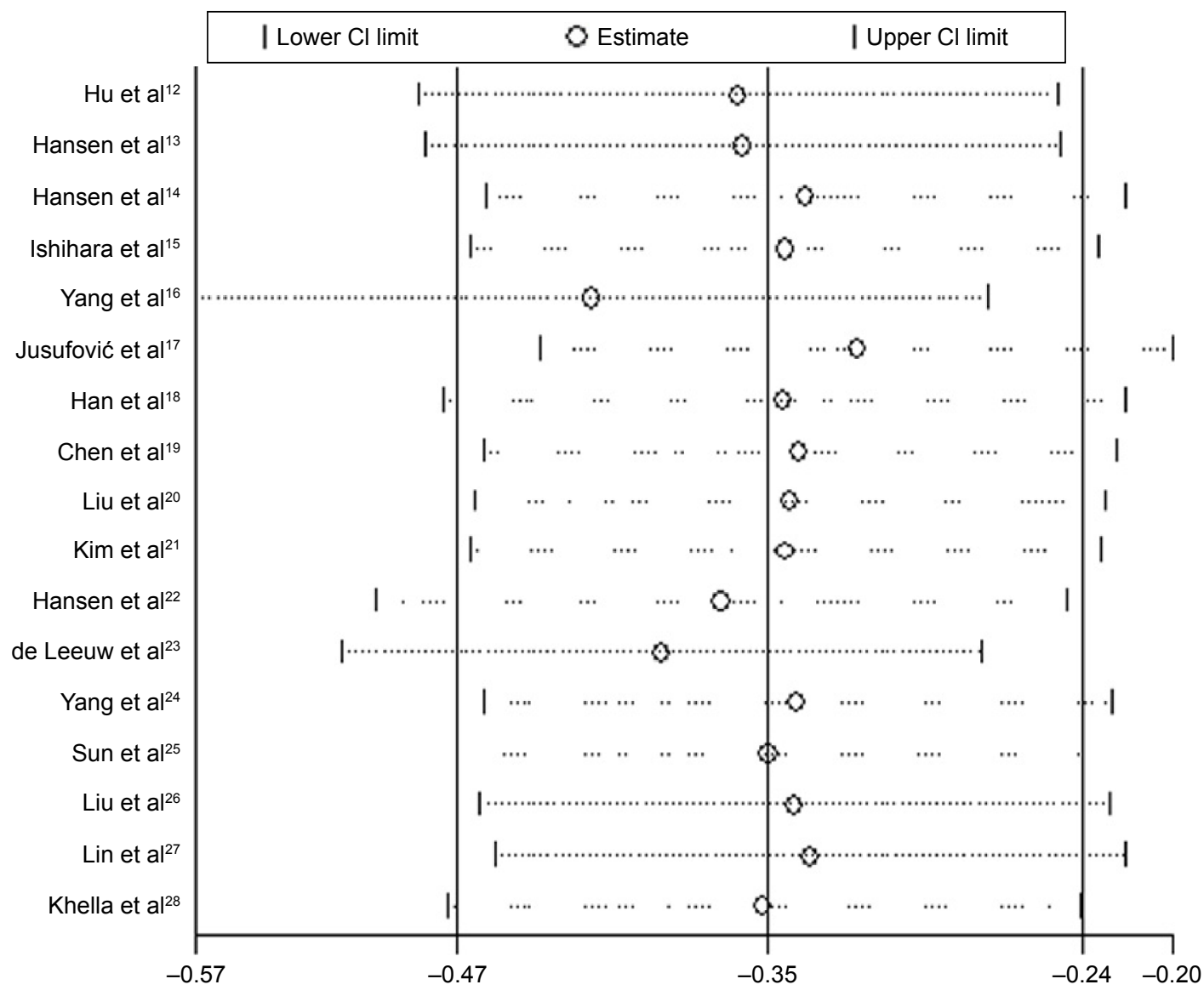

Figure 3 Sensitivity analysis for meta-analysis.

Abbreviation: $\mathrm{Cl}$, confidence interval. 


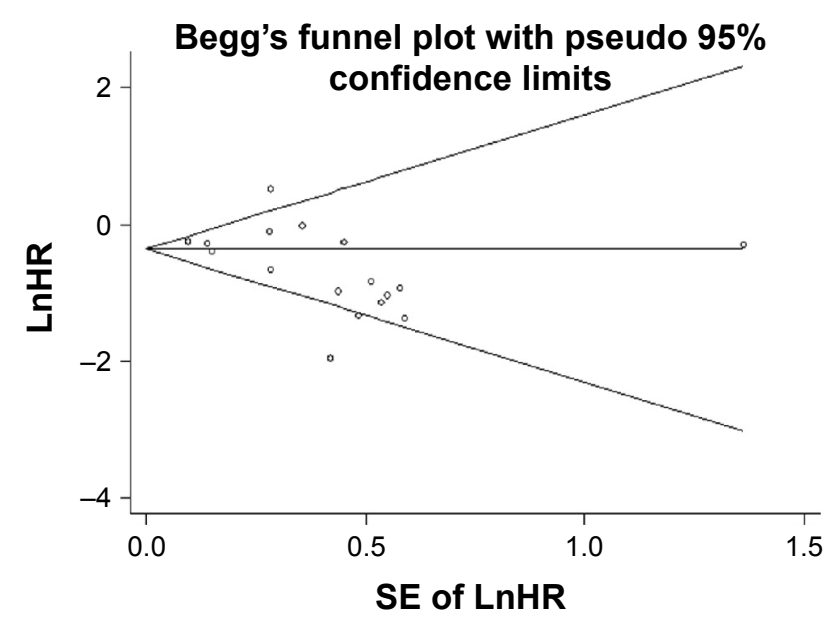

Figure 4 Funnel plot of miR- 126 and overall survival.

Abbreviations: miR-126, microRNA-126; HR, hazard ratio; SE, standard error.

of miR-126 was extensively explored in CRC. Focusing on stage II colon cancer patients, a study by Hansen et al showed that correlation between miR-126 and OS approached statistical significance (HR 0.76, 95\% CI: $0.58-1.00) .{ }^{22} \mathrm{Liu}$ et al found that CXCR4 in CRC was the target of miR-126, which contributed to poor survival of patients with low miR$126 .{ }^{20}$ However, the results of related investigations have not demonstrated concordance to the same extent. In 2008, Díaz et al divided miR-126 expression by tertiles in human colon cancer patients and did not find statistical significance in the comparison both in medium versus low expression group (HR 1.02, 95\% CI: 0.43-2.41) and in high versus low expression group (HR 0.91, 95\% CI; 0.39-2.15). ${ }^{50}$

According to our study, higher level of miR-126 predicted better OS (HR 0.70, 95\% CI: 0.62-0.79, random-effects model), especially in digestive system cancers (HR 0.70, 95\% CI: $0.59-0.83$, fixed-effects model) and respiratory system cancers (HR 0.71, 95\% CI: 0.59-0.85, randomeffects model). However, we must interpret the conclusion with caution. We believe that miRNA alone is not the ideal biomarker for cancer prognosis. In the first place, miRNA regulates multiple target mRNAs, and each target mRNA is regulated by multiple miRNAs. Moreover, regulation of miR126 mediated various signal pathways in different tissues. Its multiple functions seem to rely on the cell type and the cellular environment, which was suggested by the researches showing that not all validated miR-126 target mRNAs were affected by miR-126 in every cell type, for instance, EGFL 7. ${ }^{50,51}$ Thus, association between aberrant expression levels of miR-126 with prognosis needs further validation. In the second place, miR-126 combined with other biomarkers may be more reasonable to be used as a prognostic factor and they have already revealed an elevated prognostic power than
miR-126 alone, for instance, miR-126 combining let- $7 \mathrm{~b}^{17}$ or miR151-3p. ${ }^{36}$ We hypothesized in future clinical practice that a set of related miR may be a better option. ${ }^{37}$ Moreover, by taking all participants with varied cancer types in this meta-analysis, the favorable trend of miR-126, outweighed the absolute value of pooled HR, because, even if miR-126 was established as a critical prognostic factor like Her-2, we believe that the prognosis of patients depends on many factors, including general condition, tumor differentiation, and TNM staging. Thus, in a short term, the aim to elucidate association of miR-126 with prognosis is not to apply miR-126 in guiding clinical practice immediately; instead, it may provide some insights into designs of clinical trials or scientific research.

There are limitations to consider. First, heterogeneity in the present study amounted to $63.2 \%$. To find its source, sensitivity analysis as well as meta-regression showed no factors profoundly influencing heterogeneity. Nonetheless, according to subgroup analysis, sources of miR-126 (tissue or blood), miR-126 assay method (ISH or qRT-PCR), and data source (reported or extracted from the survival curve) may partly contribute to the heterogeneity. Therefore, we recommend future investigations to use qRT-PCR and tissue specimen in order to compare with other researches. Second, the value of Egger's test reveals a potential publication bias. To make our results more reliable, trim and fill method was subsequently performed. The HR after adjustment changed to 0.59 (0.463-0.752, $P<0.01)$, almost consistent with the unadjusted result. Thus, our result was reliable. In addition, publication bias may also contribute to heterogeneity. To reduce it, further studies enrolling more patients are needed.

\section{Conclusion}

This meta-analysis indicated that a high level of miR-126 played a favorable role in predicting patients' OS, especially for patients with digestive or respiratory system cancers. However, given the limitations of the present study, further investigations are needed.

\section{Acknowledgment}

The authors would like to acknowledge all the investigators, especially, Professor Baosheng Li, PhD, for his editorial support. This work was supported by the National Natural Science Foundation of China (81201526) and Shandong Province Natural Science Foundation (ZR2012HQ009).

\section{Disclosure}

The authors report no conflicts of interest in this work. 


\section{References}

1. Bartel DP. MicroRNAs: genomics, biogenesis, mechanism, and function. Cell. 2004;116(2):281-297.

2. Calin GA, Dumitru CD, Shimizu M, et al. Frequent deletions and down-regulation of micro-RNA genes miR15 and miR16 at 13q14 in chronic lymphocytic leukemia. Proc Natl Acad Sci U S A. 2002;99(24): 15524-15529.

3. Lu J, Getz G, Miska EA, et al. MicroRNA expression profiles classify human cancers. Nature. 2005;435(7043):834-838.

4. MikoE, CzimmererZ, CsankyE, etal. Differentially expressed microRNAs in small cell lung cancer. Exp Lung Res. 2009;35(8):646-664.

5. Meister J, Schmidt MH. miR-126 and miR-126*: new players in cancer. ScientificWorldJournal. 2010;10:2090-2100.

6. Tavazoie SF, Alarcon C, Oskarsson T, et al. Endogenous human microRNAs that suppress breast cancer metastasis. Nature. 2008; 451(7175):147-152.

7. Liu B, Peng XC, Zheng XL, Wang J, Qin YW. MiR-126 restoration down-regulate VEGF and inhibit the growth of lung cancer cell lines in vitro and in vivo. Lung Cancer. 2009;66(2):169-175.

8. Guo C, Sah JF, Beard L, Willson JK, Markowitz SD, Guda K. The noncoding RNA, miR-126, suppresses the growth of neoplastic cells by targeting phosphatidylinositol 3-kinase signaling and is frequently lost in colon cancers. Genes Chromosomes Cancer. 2008;47(11):939-946.

9. Wang X, Tang S, Le SY, Rader JS, Meyers C, Zheng ZM. Aberrant expression of oncogenic and tumor-suppressive microRNAs in cervical cancer is required for cancer cell growth. PLoS One. 2008; 3(7):e2557.

10. Otsubo T, Akiyama Y, Hashimoto Y, Shimada S, Goto K, Yuasa Y. MicroRNA-126 inhibits SOX2 expression and contributes to gastric carcinogenesis. PLoS One. 2011;6(1):e16617.

11. Resnick KE, Alder H, Hagan JP, Richardson DL, Croce CM, Cohn DE. The detection of differentially expressed microRNAs from the serum of ovarian cancer patients using a novel real-time PCR platform. Gynecol Oncol. 2009;112(1):55-59.

12. Hu Y, Correa AM, Hoque A, et al. Prognostic significance of differentially expressed miRNAs in esophageal cancer. Int J Cancer. 2011; 128(1):132-143

13. Hansen TF, Andersen CL, Nielsen BS, et al. Elevated microRNA-126 is associated with high vascular endothelial growth factor receptor 2 expression levels and high microvessel density in colorectal cancer. Oncol Lett. 2011;2(6):1101-1106.

14. Hansen TF, Sørensen FB, Lindebjerg J, Jakobsen A. The predictive value of microRNA-126 in relation to first line treatment with capecitabine and oxaliplatin in patients with metastatic colorectal cancer. $B M C$ Cancer. 2012;12(1):83.

15. Ishihara K, Sasaki D, Tsuruda K, et al. Impact of miR-155 and miR-126 as novel biomarkers on the assessment of disease progression and prognosis in adult T-cell leukemia. Cancer Epidemiol. 2012;36(6):560-565.

16. Yang J, Lan H, Huang X, Liu B, Tong Y. MicroRNA-126 inhibits tumor cell growth and its expression level correlates with poor survival in non-small cell lung cancer patients. PLoS One. 2012;7(8): e42978.

17. Jusufović E, Rijavec M, Keser D, et al. let-7b and miR-126 are downregulated in tumor tissue and correlate with microvessel density and survival outcomes in non-small-cell lung cancer. PLoS One. 2012; 7(9):e45577.

18. Han ZB, Zhong L, Teng MJ, et al. Identification of recurrence-related microRNAs in hepatocellular carcinoma following liver transplantation. Mol Oncol. 2012;6(4):445-457.

19. Chen H, Miao R, Fan J, et al. Decreased expression of miR-126 correlates with metastatic recurrence of hepatocellular carcinoma. Clin Exp Metastasis. 2013;30(5):651-658.

20. Liu Y, Zhou Y, Feng X, et al. Low expression of microRNA-126 is associated with poor prognosis in colorectal cancer. Genes Chromosomes Cancer. 2014;53(4):358-365.

21. Kim MK, Jung SB, Kim J-S, et al. Expression of microRNA miR-126 and miR-200c is associated with prognosis in patients with non-small cell lung cancer. Virchows Arch. 2014;465(4):463-471.
22. Hansen TF, Kjær-Frifeldt S, Morgenthaler S, et al. The prognostic value of microRNA-126 and microvessel density in patients with stage II colon cancer: results from a population cohort. J Transl Med. 2014;12(1):1-12.

23. de Leeuw DC, Denkers F, Olthof MC, et al. Attenuation of microRNA126 expression that drives CD34+38- stem/progenitor cells in acute myeloid leukemia leads to tumor eradication. Cancer Res. 2014;74(7): 2094-2105.

24. Yang Y, Song KL, Chang H, Chen L. Decreased expression of microRNA-126 is associated with poor prognosis in patients with cervical cancer. Diagn Pathol. 2014;9:220.

25. Sun X, Wang ZM, Song Y, Tai XH, Ji WY, Gu H. MicroRNA-126 modulates the tumor microenvironment by targeting calmodulinregulated spectrin-associated protein 1 (Camsap1). Int J Oncol. 2014; 44(5):1678-1684.

26. Liu W, Zhao ZY, Shi L, Yuan WD. Tissue microRNA-126 expression level predicts outcome in human osteosarcoma. Diagn Pathol. 2015; 10:116.

27. Lin N, Zhou Y, Lian X, Tu Y. Down-regulation of tissue microRNA126 was associated with poor prognosis in patients with cutaneous melanoma. Int J Clin Exp Med. 2015;8(3):4297-4301.

28. Khella HW, Scorilas A, Mozes R, et al. Low expression of miR-126 is a prognostic marker for metastatic clear cell renal cell carcinoma. Am J Pathol. 2015;185(3):693-703.

29. Tierney JF, Stewart LA, Ghersi D, Burdett S, Sydes MR. Practical methods for incorporating summary time-to-event data into meta-analysis. Trials. 2007;8:16.

30. Wells G, Shea B, O'connell D, et al. The Newcastle-Ottawa Scale (NOS) for Assessing the Quality of Nonrandomised Studies in Meta-Analyses. Ottawa, ON: Ottawa Hospital Research Institute; 2000.

31. Thompson AK, Kelley BF, Prokop LJ, Murad MH, Baum CL. Risk factors for cutaneous squamous cell carcinoma recurrence, metastasis, and disease-specific death: a systematic review and meta-analysis. JAMA Dermatol. Epub 2016 Jan 21:1-10.

32. Zhang R, Wang H, Zhao J, et al. Association between sodium iodide symporter and differentiated thyroid cancer: a meta-analysis of 9 studies. Int J Clin Exp Med. 2015;8(10):17986.

33. Begg CB, Mazumdar M. Operating characteristics of a rank correlation test for publication bias. Biometrics. 1994;50(4):1088-1101.

34. Egger M, Davey Smith G, Schneider M, Minder C. Bias in meta-analysis detected by a simple, graphical test. BMJ. 1997;315(7109):629-634.

35. Duval S, Tweedie R. Trim and fill: a simple funnel-plot-based method of testing and adjusting for publication bias in meta-analysis. Biometrics. 2000;56(2):455-463.

36. McNally ME, Collins A, Wojcik SE, et al. Concomitant dysregulation of microRNAs miR-151-3p and miR-126 correlates with improved survival in resected cholangiocarcinoma. HPB (Oxford). 2013;15(4):260-264.

37. Li X, Zhang Y, Zhang Y, Ding J, Wu K, Fan D. Survival prediction of gastric cancer by a seven-microRNA signature. Gut. 2010;59(5):579-585.

38. Ebrahimi F, Gopalan V, Smith RA, Lam AK. miR-126 in human cancers: clinical roles and current perspectives. Exp Mol Pathol. 2014;96(1): 98-107.

39. Miko E, Margitai Z, Czimmerer Z, et al. miR-126 inhibits proliferation of small cell lung cancer cells by targeting SLC7A5. FEBS Lett. 2011; 585(8):1191-1196.

40. Zhang J, Du YY, Lin YF, et al. The cell growth suppressor, mir-126, targets IRS-1. Biochem Biophys Res Commun. 2008;377(1):136-140.

41. Yang X, Wu H, Ling T. Suppressive effect of microRNA-126 on oral squamous cell carcinoma in vitro. Mol Med Rep. 2014;10(1):125-130.

42. Li XM, Wang AM, Zhang J, Yi H. Down-regulation of miR-126 expression in colorectal cancer and its clinical significance. Med Oncol. 2011; 28(4):1054-1057.

43. Hamada S, Satoh K, Fujibuchi W, et al. MiR-126 acts as a tumor suppressor in pancreatic cancer cells via the regulation of ADAM9. Mol Cancer Res. 2012;10(1):3-10.

44. Png KJ, Halberg N, Yoshida M, Tavazoie SF. A microRNA regulon that mediates endothelial recruitment and metastasis by cancer cells. Nature. 2012;481(7380):190-194. 
45. Zhu N, Zhang D, Xie H, et al. Endothelial-specific intron-derived miR126 is down-regulated in human breast cancer and targets both VEGFA and PIK3R2. Mol Cell Biochem. 2011;351(1-2):157-164.

46. Li N, Tang A, Huang S, et al. MiR-126 suppresses colon cancer cell proliferation and invasion via inhibiting RhoA/ROCK signaling pathway. Mol Cell Biochem. 2013;380(1-2):107-119.

47. Cappellesso R, Nicole L, Caroccia B, et al. Young investigator challenge: microRNA-21/microRNA-126 profiling as a novel tool for the diagnosis of malignant mesothelioma in pleural effusion cytology. Cancer Cytopathol. 2016;124(1):28-37.

48. Fiore D, Donnarumma E, Roscigno G, et al. miR-340 predicts glioblastoma survival and modulates key cancer hallmarks through down-regulation of NRAS. Oncotarget. Epub 2016 Jan 21.
49. Bacci M, Giannoni E, Fearns A, et al. miR-155 drives metabolic reprogramming of ER+ breast cancer cells following long-term estrogen deprivation and predicts clinical response to aromatase inhibitors. Cancer Res. Epub 2016 Jan 21.

50. Díaz R, Silva J, Garcia JM, et al. Deregulated expression of miR-106a predicts survival in human colon cancer patients. Genes Chromosomes Cancer. 2008;47(9):794-802.

51. Sun Y, Bai Y, Zhang F, Wang Y, Guo Y, Guo L. miR-126 inhibits nonsmall cell lung cancer cells proliferation by targeting EGFL7. Biochem Biophys Res Commun. 2010;391(3):1483-1489.

\section{Publish your work in this journal}

OncoTargets and Therapy is an international, peer-reviewed, open access journal focusing on the pathological basis of all cancers, potential targets for therapy and treatment protocols employed to improve the management of cancer patients. The journal also focuses on the impact of management programs and new therapeutic agents and protocols on

\section{Dovepress}

patient perspectives such as quality of life, adherence and satisfaction. The manuscript management system is completely online and includes a very quick and fair peer-review system, which is all easy to use. Visit http://www.dovepress.com/testimonials.php to read real quotes from published authors.

Submit your manuscript here: http://www.dovepress.com/oncotargets-and-therapy-journal 